\title{
VARIOUS CATEGORIES OF CHANGES IN THE INDUCEMENT OF CHANGE BLINDNESS
}

\author{
Michaela PORUBANOVÁ-NORQUIST, Radovan SIKL \\ Academy of Sciences of the Czech Republic \\ Veveri 97, 60200 Brno, Czech Republic \\ E-mail: mise199@gmail.com
}

\begin{abstract}
Change blindness represents extreme difficulty in detecting changes in the visual field induced by brief blank screen interjected in between two alternating images. In the process of searching for a change, visual saliency certainly plays an important role in attracting attention (i.e., pop-out effect). In our study, we were interested in whether there are high-level scene factors that might attract attention as well. As hypothesized, probable, central, relevant and within the figure changes were detected more easily than changes that were improbable, marginal, irrelevant and occurring within the background. Interestingly, detecting changes occurring within close proximity of the figure was most difficult. This indicates that when searching for changes in scenes, parts of the scenes close to the most powerful attractors are being shadowed, and therefore seem to be ignored by selective attention. This could be ascribed to the role of expectations in change detection task. Therefore, we believe that specifically in explicit change detection task, an individual might use certain heuristics that helps her/him scan the scene. The data are discussed in the context of the debate about the nature of scene representations.
\end{abstract}

Key words: change blindness, scene perception, flicker paradigm, attention allocation, attention

\section{INTRODUCTION}

When perceiving scenes in real life environment, we experience a feeling of having a rich visual representation of the world outside. When a change in our visual field occurs, it is accompanied by a motion signal or another transient event that automatically results in attention being redirected to this change (Klein, Kingstone, Pontefract, 1992), and the change is easily detected. What happens if a change occurs but this motion signal is absent? Many studies show that an observer in this situation has a difficulty detecting the change. The term change blindness was coined to describe a failure to notice even remarkable changes assured by the disruption of the visual continuity in the scene by presenting a change during eye movement (Bridgeman, Hendry, Stark, 1975; Hollingworth, Schrock, Henderson, 2001; Pashler, 1988), inserting a brief blank in between scenes (Fernandez-Duque et al., 2003; McCarley et al., 2004; Rensink, O'Regan, Clark, 1997, 2000; Richard et al., 2002; Scholl, 2000; Simons, Rensink, 2005), using "mudsplashes" (O'Regan, Rensink, Clark, 1999) or presenting a gradual change (Simons, Franconeri, Reimer, 2000), or movie cuts (Levin, Simons, 1997; Simons, 1996).

Over the last decade, the phenomenon of change blindness has helped generate a better understanding of visual perception, the role of attention in conscious perception, and the nature of representations and memory.

DOI: $10.21909 /$ sp.2013.02.627 
Specifically, recent findings on change blindness have challenged the traditional view of the nature of visual representations, also demonstrating that belief in richness of our visual experience is illusory or inaccurate (Blackmore et al., 1995; Levin et al., 2000). Many alternative hypotheses concerning the nature of visual representations have been proposed based on the results of change blindness research. According to the extreme view, we do not form representations of visual field at all (Noë, 2009; Noë et al., 2000). Similarly, a less extreme idea posits that we do not retain or represent the original attributes of the changed object (Dennett, 1991), or that only a very limited portion of visual information is retained through successive views of a scene made during saccades (Grimes, 1996; McConkie, Currie, 1996; McConkie, Zola, 1979) or in saccade-simulating technique called flicker technique (Rensink et al., 1997).

Other authors suggest that a representation of the visual scene is created, but change blindness occurs because the memory trace is very volatile (Wolfe, 1999), replaced by the post-change presented stimuli (Rensink et al., 1997; Simons, 2000), or that representation of a change occurs but it is not overly reportable, however, this implicit change detection can be manifested in subsequent behavior (Fernandez-Duque, Thorton, 2000, 2003; Laloyaux, Destrebecqz, Cleeremans, 2006).

In terms of change blindness research, little attention has been paid to stimulus properties and their effect on inducing change blindness (although there are studies that tried to explore this issue, e.g., Beck, Angelone, Levin, 2004; Mazza, Turatto, Umilta, 2005; O’Regan, Rensink, Clark, 1999; Rensink et al., 1997; Turatto et al., 2002). Considering the great diversity in scenes and stimulus (change) properties, we assume that the inducement of change blindness for a particular kind of change is not random, therefore, not all changing stimulus properties will result in the same effect on the inability to detect changes occurring in a scene. Research on eye movements (Henderson, Hollingworth, 1999; Hollingworth, Henderson, 2002) has shown that changes tend to be observed when pre-change and post-change regions are fixated (thus attended to). This is supported by the results of Rensink et al. (1997) illustrating that changes occurring in regions of high interest (changes in objects listed in a prior-testing verbal description of a scene by participants) are detected faster than changes in regions of low interest. It means that regions of high interest were being attended to more frequently. Based on this research, it can be concluded that focused attention plays a tremendous role in successful (i.e., reportable and correct) change detection. Turatto et al. (2002) examined change detection in simple geometrical displays using one-shot paradigm, where change detection was highly preferential for the figure. Mazza et al. (2005) found that changes in the background were detected only when attention was focused on them, whereas changes in the figure were detected invariably.

Not only localization of the change is crucial for the speed and accuracy of change detection, but also the character of change. For instance, Hollingworth and Henderson (2000) showed that detection of semantically inconsistent objects in a scene in a flicker task is faster and more accurate than in the case of semantically consistent objects. The results indicate that we do concoct some kind of visual representation when perceiving scenes, although it can be very poor and 
schematic. Supported by the current research on scene perception, the nature of scene representations, therefore, does not seem to be detailed or picture-like. The assumption that we do not create representations at all is somewhat misleading and oversimplified.

There is ample evidence from research we believe to be "middle ground", that out of all the information in a scene, the predominantly important information will be encoded and represented. The determination of which information will be considered important by human visual system will depend both on high-level and low-level factors. It is clear that low-level scene factors such as hue, illumination, color, orientation, edges and movement play a crucial role in attracting attention. However, especially in active tasks (such as change detection), particularly highlevel scene factors influence attention allocation toward important parts of the scene (Henderson, 2003; Henderson, Hollingworth, 2002).

The aim of this research study was to understand how high-level scene determinants modulate attention in change detection task. We included the following high-level change properties for the purposes of our experiment: 1) central/marginal changes, 2) changes concerning figure/background relationship, 3 ) relevance of the change to the scene context, and 4) probability of a change.

Centrality/marginality. The changes in this category were divided into central or marginal depending on the degree of interest of the scene region in which a change occurred (similar to Rensink et al., 1997). However, contrary to Rensink et al. (1997), who divided the changes based on the frequency of objects mentioned in verbal description, we decided to have 4 independent researchers evaluate each change as being central or marginal. This evaluation was based on the localization of a change, i.e. how centrally or marginally it was localized.

Relevance of a change to the scene context. When performing a specific goal-oriented task (i.e., being influenced by top-down processing), attention is guided toward relevant visual stimuli while ignoring presented distracters (Engle, 2000; Engle, 2002; Engle, Kane, Tuholski, 1999; Wolfe, 1994). Information irrelevant to the scene context should therefore be disregarded and information relevant to the context will be prominent in the scanning of the scene. We hypothesize that this tendency will result in faster detection of context-relevant than context-irrelevant changes (e.g., a phone being removed from a scene where a person is talking on the phone versus a scarf being removed from the talking person's neck).

Probability of the change. Phenomena, such as boundary extension and representational momentum, have demonstrated that perception is not momentary, but that it is focused on prediction of the future (Intraub, 2002; Munger et al., 2005). We hypothesize that in change detection task, one's expectations of what kind of change could possibly occur are dominant. Therefore, attention will be allocated to changes that are probable. Based on this, we believe that when presented with a natural scene, a tendency to predict the future outcome plays a role in scene perception and that probable changes should be detected faster than improbable ones for this reason.

Figure-ground localization. Localization of a change in central or marginal region of a scene is not always identical to figureground segmentation, whereas the latter consists in a formation of perceptual units based on the greater saliency for the figure, regard- 
less of its visual saliency properties (Rubin, 1921). However, both the figure and the central region of the scene are considered to be the initial point of scanning. We hypothesize that changes occurring in the figure will, for this reason, be detected faster than changes occurring in the background. In terms of the figure-ground localization category, we were inspired by the studies of Turrato et al. (2002) and Mazza et al. (2005) who used the oneshot paradigm for simple stimuli. We, however, used naturalistic scenes hypothesizing that change blindness will be more attenuated for background changes than figure changes. We have created one more subcategory within the figure-ground category. Intuitively, we believe that regions around the figure but considered to be part of the background, should be specific due to their ambiguous nature. They are surrounding the most salient region, i.e., the figure, but might be somewhat uninformative, since the figure and background provide us with more information, such as spatial relationships between the figure and other objects in the background. How would this affect change detection?

\section{METHOD}

\section{Participants}

8 (5 female and 3 male) volunteers with normal to corrected-to-normal vision participated in the study (mean age 21 years; range 19-26 years).

\section{Stimuli}

30 pairs of photographed outdoor and indoor naturalistic scenes were selected for the experiment. Each image could be specified as containing certain number of objects (comparable number) as well as contexts. The two images in every image pair differed from each other only in one single change that occurred. All objects as well as the context that the objects were part of were typical for the scenes presented. The size of the images was $27^{\circ}$ wide and $18^{\circ}$ high (or reverse).

In all cases, changes were quite large and easy to see once noticed. Also, all changes involved a disappearance of an object/region of a scene.

\section{Procedure}

In the experiment, the original flicker paradigm designed by Rensink et al. (1997), in which two displays of naturalistic scenes were separated by an intervening blank and alternated until change is detected, was used. The method consists in presentation of two images (original and modified) in sequence, until the change between the two images is found. Each image was presented for $240 \mathrm{msec}$ and two images in succession were separated by a blank field that was presented for $80 \mathrm{msec}$. The images were presented in random order. The experiment was conducted using the experimental software PXLab (Irtel, 2007) and it was conducted in an adequately illuminated room. The images were displayed on a 17-in. desktop (Fujitsu Siemens) computer screen (resolution $800 \mathrm{x}$ 600 pixels, $75 \mathrm{~Hz}$ ) subtending visual angles of $24^{\circ}$ (horizontal) and $18^{\circ}$ (vertical) at a viewing distance of $50 \mathrm{~cm}$.

All participants were tested individually. The experimenter explained to the participant the nature of the experiment (change detection experiment) and described the task. Then, as part of the training, two items were presented (they were not part of the experi- 
mental set). After the completion of the training, the experimental part was initiated. The participants were given a description of the experiment (without revealing the gist of the study) prior to the actual testing. They were instructed to click on the location of the change using a mouse as soon as they perceived the change between the two alternating images. If a participant was not able to detect the change within this time, alternation between the two images continued for a minute. Subsequently, the images disappeared and presentation of new set of images was initiated. Reaction time as well as location and identification of change were registered.

The only type of the changes that was presented consisted in disappearance of an object or a part of the scene from the scene. The changes that occurred between the original and modified image could be described as obvious when not presented with a scene disruption (as in the flicker technique). In this case, the participants were able to notice change immediately.
In total, 30 images for each change category were presented. In each image, a change was presented classified according to a specific category (e.g., central-marginal). In each set, equal number of changes from each subcategory was presented. Low-level properties (determined by luminance, hue and size) of the changes were controlled for.

The assignment of changes into each subcategory was executed by four experts and was included in the experiment only when all experts assigned the change to the same category.

\section{RESULTS}

Percentage of detected trails. Trials in which participants were not able to respond within $60 \mathrm{~s}$ were excluded from the study (as in the original experiment by Rensink et al., 1997). Altogether, 6 trials were excluded. However, following percentages of detected trials (detection within $60 \mathrm{~s}$ limit) in terms of change categories were observed: For centrality/marginality condition: $100 \%$ of cen-

Table 1. Individual change categories used in the experiment

\begin{tabular}{|l|l|l|l|l|}
\hline $\begin{array}{l}\text { Change } \\
\text { Category }\end{array}$ & $\begin{array}{c}\text { Centrality/ } \\
\text { Marginality }\end{array}$ & Context Relevance & Probability & Figure / Ground \\
\hline & $\begin{array}{l}\text { Central } \\
\text { Occurring } \\
\text { within the } \\
\text { central scene } \\
\text { region }\end{array}$ & $\begin{array}{l}\text { Relevant } \\
\text { Change important } \\
\text { for maintaining the } \\
\text { scene context - i.e., } \\
\text { change changes } \\
\text { scene context }\end{array}$ & $\begin{array}{l}\text { Probable } \\
\text { possible to } \\
\text { occur in real } \\
\text { world } \\
\text { environment }\end{array}$ & $\begin{array}{l}\text { Figure } \\
\text { dominant element } \\
\text { of the scene } \\
\text { regardless of its } \\
\text { localization/ } \\
\text { centrality }\end{array}$ \\
\cline { 2 - 6 } & $\begin{array}{l}\text { Marginal } \\
\text { Occurring } \\
\text { outside of the } \\
\text { central scene } \\
\text { region }\end{array}$ & $\begin{array}{l}\text { Change does not } \\
\text { change scene } \\
\text { context }\end{array}$ & $\begin{array}{l}\text { Change that } \\
\text { could not } \\
\text { occur in real } \\
\text { world }\end{array}$ & $\begin{array}{l}\text { Change outside of } \\
\text { the dominant } \\
\text { element of the } \\
\text { scene }\end{array}$ \\
\hline
\end{tabular}


tral changes were detected; $93 \%$ of marginal changes were detected. For relevance of the change condition: $99 \%$ of relevant changes were detected, whereas $94 \%$ of irrelevant changes were detected. For probability condition: $100 \%$ of the probable changes were detected in comparison to $95 \%$ of improbable changes. For figure/background condition: $100 \%$ of changes occurring within the figure were detected within $60 \mathrm{~s} ; 95 \%$ of changes within background and $91 \%$ of changes within close proximity to the figure were detected.

Reaction time analysis. The reaction times in the trials were computed using Analysis of Variance.

The central changes were detected much faster than the marginal ones $\mathrm{F}(1,179)=$ $17.701, \mathrm{p}<.001, \mathrm{MC}=6.39, \mathrm{MM}=14.56$. The results are consistent with the report of Rensink et al. (1997) who found a preference for central changes in change detection tasks. This might be attributed to the fact that the central region is the most salient one and it is also the primary focus of attention. Relevant changes were identified in a shorter time period than irrelevant changes $\mathrm{F}(1,179)=16.635, \mathrm{p}<.001, \mathrm{MR}=4.09, \mathrm{M} \mathrm{Ir}=$ 12.91. Hollingworth and Henderson (2000) or Loftus and Mackworth (1967) demonstrated that inconsistent objects in a scene are detected sooner and remembered better than consistent ones. As in the case of inconsistent objects, information relevant to the scene context is important for the understanding of the scene context, therefore, a change in this information was found to be detected earlier. Furthermore, probable changes were detected faster than improbable changes $\mathrm{F}(1,178)=6.66, \mathrm{p}<.001 ; \mathrm{MP}=$ $5.02, \mathrm{M} \mathrm{Im}=13.35$. The result is consistent with other research (Beck et al., 2004), which found that probable changes are detected faster than improbable ones. Finally, changes in the figure were detected faster than changes in the background. However, changes occurring in the proximity of the figure were detected on average even slower than changes in the background $\mathrm{F}(2,178)=$ $7.59, \mathrm{p}<.001 ; \mathrm{M} \mathrm{F}=4.33, \mathrm{M} \mathrm{B}=12.09$, $\mathrm{M}$ Pf $=14.08$. The last two results will be further interpreted in the Discussion.

Table 2. Values for individual subcategories of changes, M, SD

\begin{tabular}{|l|r|r|}
\hline & Mean & Standard Deviation \\
\hline Centrality/Marginality & 6.39 & 3.97 \\
\hline Central & 14.56 & 7.77 \\
\hline Marginal & 4.09 & 2.65 \\
\hline Context Relevance & 7.26 \\
\hline Relevant & 12.91 & 2.16 \\
\hline Irrelevant & 5.02 & 7.81 \\
\hline Probability & 13.35 & 2.60 \\
\hline Probable & 4.33 & 7.27 \\
\hline Improbable & 12.09 & 7.75 \\
\hline Figure / Ground & 14.08 & \\
\hline Figure & \multicolumn{1}{|l}{} \\
\hline Ground &
\end{tabular}




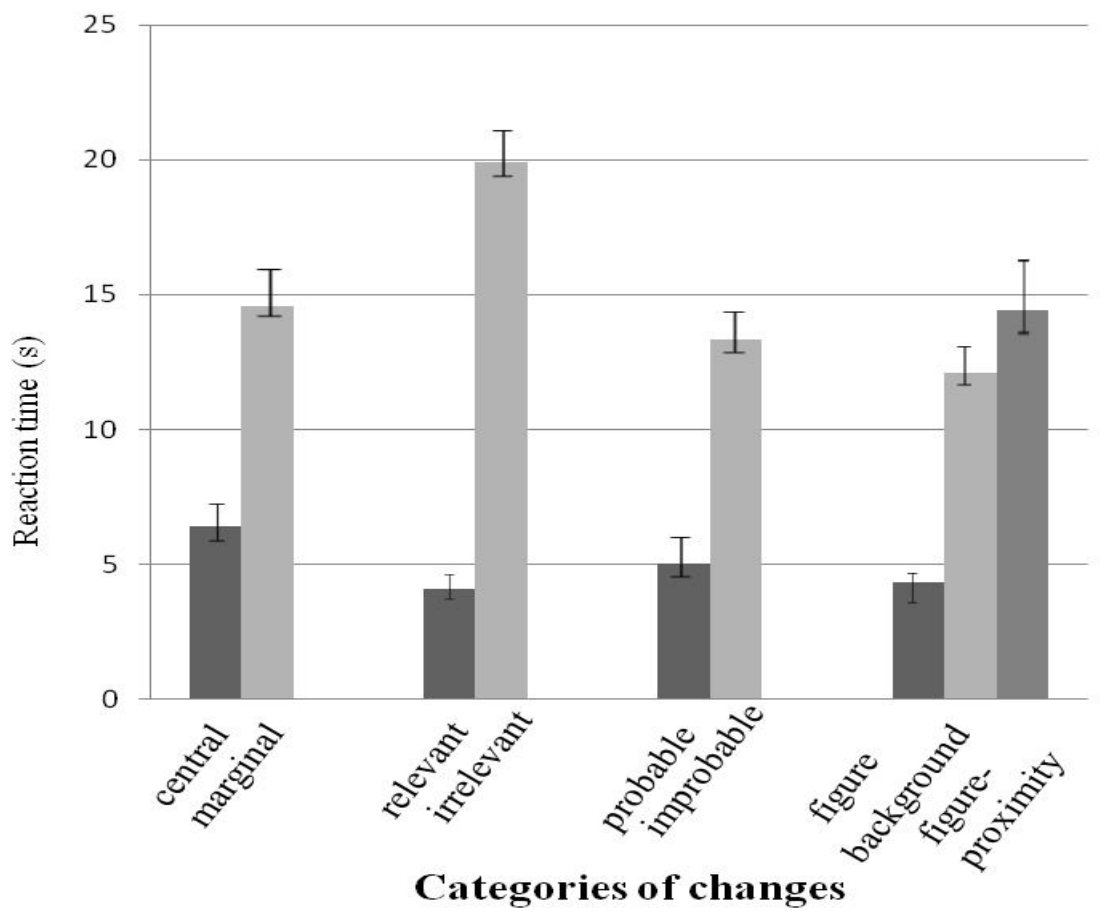

Figure 1. Categories of changes

\section{DISCUSSION}

Our experiment was motivated by several facts. First of all, the discovery of the phenomenon called change blindness illustrates that even important and remarkable changes go unnoticed. Secondly, scene perception research shows that human visual system has a tendency to attend predominantly to informative and important parts of a scene (Buswell, 1935; Henderson, 2003; Loftus, Mackworth, 1978; Yarbus, 1967). Lastly, in active tasks such as change detection attending to information with high visual saliency (i.e., spatial frequency, color, and in- tensity) is inhibited (Henderson, 2003; Henderson, Hollingworth, 2003; Turano, Geruschat, Baker, 2003), therefore, attention is rather dependent on the high-level factors (Beck et al., 2004; Hollingworth, Henderson, 2000; Rensink et al., 1997). Taken together, one could hypothesize that high-level factors will determine which parts of a scene are important and which ones are not and this distinction will influence the extent to which the changes in those regions will be detected. The focus of the present study was to explore which high-level scene information is considered informative and important by human visual system. We believe that real-world scene perception can provide us 
with better understanding of the functioning of the visual system due to its higher ecological validity, since coherent images (i.e., natural scenes) seem to be processed by the visual system more naturally (Biederman, 1972, 1981; Henderson, 2003; Rensink, 2000).

In the experiment, observers inspected various real-world scene images alternating in sequential order (i.e., flicker task) and were asked to click on the location where a change occurred once they perceived it. The results demonstrate that not all changes present in a scene are of the same likelihood to be detected. The interesting changes that seem to be dominant in attracting attention were found to be changes occurring in the central region, context-related changes, probable changes and changes occurring in the figure. Our results are consistent with the results of other studies. For instance, research on scene perception has shown that changes in the central region are detected faster than in the marginal area (Rensink et al., 1997), changes inconsistent with the scene context are detected faster than the ones consistent with the scene context (Hollingworth, Henderson, 2000), probable changes faster than improbable ones (Beck et al., 2004) and changes in the figure are detected to a greater extent than the ones in the background (Mazza et al., 2005; Turatto et al., 2002). Therefore, the individual results in our experiment are not very surprising. On the other hand, this study offers extensive comparison of various high-level scene factors in their influence on change detection.

In terms of change blindness research, we consider especially interesting the results in the category figure-background and probability-improbability.
Figure-background. Each image is automatically segmented by the visual system into figure and background; where figure is the most salient region of the scene regardless of its visual saliency (Wertheimer, 1923), and therefore the observer's initial attention is devoted to the inspection of the figure. Mazza et al. (2005) report on the results of change blindness for stimuli in foreground versus background, which suggest that by default the figure is the primary target of attentional focus. It is therefore not very surprising that in our experiment change detection was preferential for figure changes in comparison with background changes. On the contrary, rather surprising is the finding that participants needed on average even more time for detection of changes presented in the near proximity of the figure. How could one interpret this finding? As previously mentioned, figure is the primary target of our attention. However, once one's gaze is directed onto the figure and no change is found, top-down factors (i.e., expectations of an individual) become dominant in gaze guidance. As an individual might believe that the region of the figure was sufficiently inspected, s/he will focus the attention outside of the figure, directing it to other parts of the scene in the background. However, when no change is found in the background, s/he will return to explore the figure at last. Thus, we believe that this heuristic in gaze guidance in change detection task might help to explain this pattern of data.

Probability. We found that probable changes were detected faster than improbable changes. We suppose that this could be explained by the fact that when perceiving real-world images, expectations derived from knowledge play an important role in 
encoding and memorizing information. In change detection task, attention should, therefore, be directed toward those stimuli that are believed to have properties that can be changed in contrast with changes that do not occur in real-life environment (rf. Beck et al., 2004). For the change detection paradigm, we believe that this category is especially important. Change detection is deemed an active task in which top-down influence is particularly dominant (Henderson, 2003; Henderson, Hollingworth, 2003), therefore, the subjects' expectations about possibly occurring changes can play an essential role in directing attention.

It is important to mention that the changes presented within this category were not too peculiar, so attention would not have been primarily caught by this "peculiarity" occurring in the scene, but rather the subjects' expectations would have been the influencing factor of attentional guidance. In this aspect the design of our experiment differed from Loftus and Mackworth (1978) and Hollingworth and Henderson (2000) who showed that objects that are not consistent with the scene context or do not belong to the scene context are remembered much more that the consistent ones.

\section{CONCLUSION}

In general, not all (even) remarkable changes will induce change blindness. This inducement is also contingent upon several non-visual, semantic properties that the particular change possesses. Based on this, one can interpret many results of previous change (and inattentional) blindness studies. For instance, in the movie by Levin and Simons (1997), when during a movie cut a person's identity as well as clothes change, people fail to notice it. However, this change has certain attributes that decrease the likelihood of people detecting it. Is this change probable? Would this change occur in normal circumstances (i.e., in normal life)? How important is this change for the context presented in the movie? The actor is probably identified as a tall, skinny, good-looking, glasses-wearing, blond hair man, and those attributes do not change remarkably. We suppose that if more probable change occurred, for instance the man would discard his glasses, it would be more easily detected.

The article discusses the significance of the categories under which stimulus in terms of its non-visual or semantic properties falls. We agree with the idea that visual representations are rather sparse, not detailed, but we also believe that certain properties are represented.

The wealth of visual information is dependent on both visual and non-visual properties, but especially in a real-world scene, perception attention is heavily biased by nonvisual and semantic properties. In active tasks, change detection is strategic and contingent upon properties of higher-level scene components (e.g., objects' properties), and those properties will have priority in the process of being represented.

It could be contested that real-world environment does not engage the visual system in such tasks such as intentional change detection. Regardless of this fact, we believe that studies on change blindness can reveal invaluable information about the way visual system codes, utilizes and retains information through successive fixations.

Received November 30, 2012 


\section{REFERENCES}

BECK, M.R., ANGELONE, B.L., LEVIN, D.T., 2004, Knowledge about the probability of change affects change detection performance. Journal of Experimental Psychology: Human Perception and Performance, 30, 4, 778-791.

BIEDERMAN, I., 1972, Perceiving real world scenes. Science, 177, 77-80.

BIEDERMANN, I., 1981, On the semantics of a glance at a scene. In: J.M. Kubovy, J.R. Pomerantz (Eds.), Perceptual organization (pp. 213-253). Hillsdale, NJ: Lawrence Erlbaum Associates, Inc.

BIEDERMAN, I., MEZZANOTTE, R.J., RABINOWITZ, J.C., 1982, Scene perception: Detecting and judging objects undergoing relational violations. Cognitive Psychology, 14, 143-177.

BLACKMORE, S.J., BRELSTAFF, G., NELSON, K., TROSCIANKO, T., 1995, Is the richness of our visual world an illusion? Transsaccadic memory for complex scenes. Perception, 24, 1075-1081.

BRIDGEMAN, B., HENDRY, D., STARK, L., 1975, Failure to detect displacement of the visual world during saccadic eye movements. Vision Research, 15, 719-722.

BUSWELL, G.T., 1935, How People Look at Pictures. Chicago: University of Chicago Press.

CASTELHANO, M.S., HENDERSON, J.M. 2008, The influence of color on the activation of scene gist. Journal of Experimental Psychology: Human Perception and Performance, 34, 660-675.

DENNETT, D., 1991, Consciousness explained. Boston: Little Brown.

ENGLE, R.W., 2002, Working memory capacity as executive attention. Current Directions in Psychological Science, 11, 19-23.

ENGLE, R.W., KANE, M.J., TUHOLSKI, S.W., 1999, Individual differences in working memory capacity and what they tell us about controlled attention, general fluid intelligence, and functions of the prefrontal cortex. In: A. Miyake, P. Shah (Eds.), Models of working memory: Mechanisms of active maintenance and executive control (pp. 102-134). Cambridge, UK: Cambridge University Press.

FERNANDEZ-DUQUE, D., THORNTON, I.M., 2000, Change detection without awareness: Do explicit reports underestimate the representation of change in the visual system? Visual Cognition, 7, 13, 323-344.

FERNANDEZ-DUQUE, D., THORNTON, I.M. 2003, Explicit mechanisms do not account for im- plicit localization and identitication of change: An empirical reply to Mitroff et al. (2002). Journal of Experimental Psychology: Human Perception and Performance, 29, 5, 846-858.

FERNANDEZ-DUQUE, D., GROSSI, G., THORNTON, I.M., NEVILLE, H.J., 2003, Representation of change: Separate electrophysiological markers of attention, awareness, and implicit processing. Journal of Cognitive Neuroscience, 15, 4, 491-507.

GRIMES, J., 1996, On the failure to detect changes in scenes across saccades. In: K. Akins (Ed.), Perception (pp. 89-109). New York: Oxford University Press.

HENDERSON, J.M., 2003, Human gaze control in real-world scene perception. Trends in Cognitive Sciences, 7, 11, 498-504.

HENDERSON, J.M., HOLLINGWORTH, A., 1999, The role of fixation position in detecting scene changes across saccades. Psychological Science, 10, 438-443.

HOLLINGWORTH, A., HENDERSON, J.M., 2000 , Semantic informativeness mediates the detection of changes in natural scenes. Visual Cognition (Special Issue on Change Blindness and Visual Memory), 7, 213-235.

HOLLINGWORTH, A., HENDERSON, J.M., 2002, Accurate visual memory for previously attended objects in natural scenes. Journal of Experimental Psychology: Human Perception and Performance, 29, 388-403.

HOLLINGWORTH, A., SCHROCK, G., HENDERSON, J.M., 2001, Change detection in the flicker paradigm: The role of fixation position within the scene. Memory and Cognition, 29, 296304.

INTRAUB, H., 2002, Anticipatory spatial representation of natural scenes: Momentum without movement? Visual Cognition, 9, 93-119.

IRTEL, H., 2007, PXLab: The Psychological Experiments Laboratory [online]. Version 2.1.11. Mannheim (Germany): University of Mannheim.

KLEIN, R.M., KINGSTONE, A., PONTEFRACT, A., 1992, Orienting of visual attention. In: K. Rayner (Ed.), Eye movements and visual cognition: Scene perception and reading (pp. 46-65). New York: Springer.

LALOYAUX, C., DESTREBECQZ, A., CLEEREMANS, A., 2006, Implicit change identification: A replication of Fernandez-Duque and Thornton (2003). Journal of Experimental Psychology: Human Perception and Performance, 32, 6, 1366-1379. 
LOFTUS, G.R., MACKWORTH, N.H., 1978, Cognitive determinants of fixation location during picture viewing. Journal of Experimental Psychology: Human Perception and Performance, 4, 565 572 .

LEVIN, D.T., SIMONS, D.J., 1997, Failure to detect changes to attended objects in motion pictures. Psychonomic Bulletin and Review, 4, 501506.

LEVIN, D.T., MOMEN, N., DRIVDAHL, S.B., SIMONS, D.J., 2000, Change blindness blindness: The metacognitive error of overestimating change-detection ability. Visual Cognition, 7, 397412 .

MAZZA, V., TURATTO, M., UMILTA, C., 2005, Foreground-background segmentation and attention: A change blindness study. Psychological Research, 69, 201-210.

MCCARLEY, J.S., VAIS, M.J., PRINGLE, H.L., KRAMER, A.F., IRWIN, D.E., STRAYER, D.L., 2004, Conversation disrupts change detection in complex traffic scenes. Human Factors, 46, 424 436.

MCCONKIE, G.W., CURRIE, C.B., 1996, Visual stability while viewing complex pictures. Journal of Experimental Psychology: Human Perception and Performance, 22, 563-581.

MCCONKIE, G.W., ZOLA, D., 1979, Is visual information integrated across successive fixations in reading? Perception and Psychophysics, 25, 221224

MUNGER, M.P., OWENS, T.R., CONWAY, J.E., 2005, Are boundary extension and representational momentum related? Visual Cognition, 12, 1041-1056

NOË, A., 2009, Out of our heads: Why you are not your brain, and other lessons from biology of consciousness. New York: Hill \& Wang.

NOË, A., PESSOA, L., THOMPSON, E., 2000, Beyond the grand illusion: What change blindness really teaches us about vision. Visual Cognition, 7 , 1/2/3, 93-106.

O'REGAN, J.K., 1992, Solving the "real" mysteries of visual perception: The world as an outside memory. Canadian Journal of Psychology, 46, 3 461-488.

O'REGAN, J.K., NOË, A., 2001, Acting out our sensory experience. Behavioral \& Brain Sciences, 24, 955-975.

O'REGAN, J.K, DEUBEL, H., CLARK, J.J., RENSINK, R., 2000, Picture changes during blinks: Looking without seeing and seeing without looking. Visual Cognition, 7, 1-3, 191-211.
O'REGAN, J.K., RENSINK, R.A., CLARK, J.J., 1999, Change blindness as a result of "mudsplashes". Nature, 398, 34.

PASHLER, H., 1988, Familiarity and visual change detection. Perception \& Psychophvsics, 44, 369-378.

RENNINGER, L.W., MALIK, J., 2004, When is scene identification just texture recognition. Vision Research, 44, 19, 2301-2311.

RENSINK, R.A., O'REGAN, J.K., CLARK, J.J., 1997, To see or not to see: The need for attention to perceive changes in scenes. Psychological Science, 8, 368-373.

RENSINK, R.A., O'REGAN, J.K., CLARK, J.J., 2000 , On the failure to detect changes in scenes across brief interruptions. Visual Cognition, 7, 127145.

RENSINK, R., 2000, Scene perception. In: A.E. Kazdin (Ed.), Encyclopedia of Psychology (Vol.7, pp. 151-155). New York: Oxford University Press.

RICHARD, C.M., WRIGHT, R.D., EE, C., PRIME, S.L., SHIMIZU, Y., VAVRIK, J., 2002, Effect of a concurrent auditory task on visual search performance in a driving-related image-flicker task. Human Factors, 44, 108-119.

SCHOLL, B.J., 2000, Attenuated change blindness for exogenously attended items in a flicker paradigm. Visual Cognition, 7, 377-396.

SIMONS, D.J., 1996, In sight, out of mind: When object representations fail. Psychological Science, 7, 301-305.

SIMONS, D.J., 2000, Current approaches to change blindness. Visual Cognition, 7, 1-15.

SIMONS, D.J., CHABRIS, C.F., 1999, Gorillas in our midst: Sustained inattentional blindness for dynamic events. Perception, 28, 1059-1074.

SIMONS, D.J., LEVIN, D.T., 1997, Change blindness. Trends in Cognitive Sciences, 1, 261-267.

SIMONS, D.J., RENSINK, R.A., 2005, Change blindness: Past, present, and future. Trends in Cognitive Sciences, 9, 1, 16-20.

SIMONS, D.J., FRANCONERI, S.L., REIMER, R.L., 2000, Change blindness in the absence of a visual disruption. Perception, 29, 1143-1154.

TURANO, K.A., GERUSCHAT, D.R., BAKER, F.H., 2003, Oculomotor strategies for the direction of gaze tested with a real-world activity. Vision Research, 43, 333-346

TURATTO, M., ANGRILli, A., MAZZA, V., UMILTA, C., DRIVER, J., 2002, Looking without seeing the background change: Electrophysiological correlates of change detection versus change blindness. Cognition, 84, B1-B10. 
VARAKIN, D.A., LEVIN, D.T., COLLINS, K.M., 2007, Comparison and representation failures both cause real-world change blindness. Perception, 36, 5, 737-749

WERTHEIMER, M., 1923, Untersuchungen zur Lehre von der Gestalt, II. Psychologische Forschung, 4, 301-350.
WOLFE, J.M., 1999, Inattentional amnesia. In: V. Coltheart (Ed.), Fleeting memories (pp. 71-94). Cambridge, MA: MIT Press.

YARBUS, A.F., 1967, Eye Movements and Vision. New York: Plenum Press.

\title{
RÔZNE KATEGÓRIE ZMIEN V PODNETOCHSLEPOTY VOČIZMENÁM
}

\author{
M. Poruba nová - N or qui st, R. S i k 1
}

Súhrn: Slepota voči zmenám (change blindness) je definovaná ako neschopnost' detekovat' zmeny vo vizuálnom svete, v prípade ak je zmena vložená medzi dva alternujúce vizuálne obrazy. Dôležitú úlohu v procese vyhl'adávania zmeny zohráva vizuálna saliencia (pop-out efekt). V našej štúdii sme sa zaujímali o pochopenie úlohy high-level faktorov pri detekovaní zmien. Zmeny, ktoré boli pravdepodobné, centrálne, relevantné a v oblasti figúry boli detekované rýchlejšie ako zmeny nepravdepodobné, marginálne, irelevantné a zmeny, ktoré boli súčastou pozadia. Zaujímavým zistením bolo, že zmeny $\mathrm{v}$ okolí figúry boli identifikované $\mathrm{s}$ najväčšími komplikáciami. Naša štúdia ponúka zaujímavé implikácie pre oblast’ high-level scénovej percepcie: pri vyhl'adávaní zmien, časti scén, ktoré sú v blízkej proximite k najsilnejším atraktorom sú ignorované selektívnou pozornost’ou. Tento výsledok je možné pripísat' úlohe očakávaní v detekovaní zmien, ktoré sa premietajú do oblasti používania heuristík pri skenovaní vizuálnej scény. Výsledky podávajú takisto dôležité implikácie o povahe vizuálnych reprezentácií, ktorá je diskutovaná v článku. 